\title{
RESEARCH ARTICLE \\ THE FUZZY COMPREHENSIVE EVALUATION OF AGRICULTURE ENGINEERING TEACHING
}

\author{
Bao Liangliang \\ Yulin University, China \\ *Corresponding Author Email: baoliang@qq.com
}

This is an open access article distributed under the Creative Commons Attribution License, which permits unrestricted use, distribution, and reproduction in any medium, provided the original work is properly cited

\section{ARTICLE DETAILS}

\section{Article History:}

Received 23 November 2018 Accepted 26 December 2018 Available online 21 January 2019

\section{ABSTRACT}

The evaluation process of agriculture engineering teaching is multi-level with multi-factors and prone to be affected by subjective factors. In reference to the experience and methods of EU in the optimization of higher education and teaching, this paper constructs the teaching quality evaluation index system according to the actual situation of the classroom teaching while considering the major setup and geographical distribution of agriculture engineering. A questionnaire survey is conducted on the professors, employers, students and graduates of five colleges and universities, and on this basis, the fuzzy mathematics theory is adopted to analyze the data with the fuzzy comprehensive evaluation method. The evaluation of the current situation of agriculture engineering teaching is obtained to provide a reference for the further deepening of teaching reform. The results show that this method can effectively improve the accuracy, objectivity and rationality of the evaluation.

\section{KEYWORDS}

optimization of agriculture engineering, fuzzy comprehensive evaluation, professional competence, general ability

\section{INTRODUCTION}

The ultimate goal of schools is to improve the quality of teaching, and the teaching quality assessment is an important condition to test the qualification of the school. As the first year of the $13^{\text {th }}$ Five Year Plan, the year of 2016 is one bridging the past and the future. Agriculture engineering as the basic major of agriculture is still favored by the society, so the social demand for talents of agriculture engineering in recent years is steadily increasing [1]. In this context, the urgent problem to be solved is how to guarantee and improve the teaching quality of agriculture engineering.

A full understanding of the characteristics of agriculture engineering and its corresponding teaching is the basis for improving its teaching quality, and a targeted and distinctive teaching quality evaluation system in consistent with the professional characteristics is required to truly improve the quality of professional teaching [2]. Compared with other engineering majors, agriculture engineering has the different teaching laws of intuition, applicability and visualization besides the common characteristics. The teaching process has been carried out around two aspects: general ability and professional competence. Meanwhile, due to the diverse teaching contents and students 'personalities, the class is very free and flexible. The teachers' teaching is no single lecturing but close combination of instruction and mentoring. Plenty of time is spent in cultivating the students 'comprehensive quality and improving creative ability and professional performance [3].

At present, the teaching evaluation in many Schools of Architecture is still conducted with the traditional qualitative analysis, which is proved by the practice to be one-sided, subjective, and inapplicable to the evaluation of different segments of agriculture engineering. Based on this, this paper, taking agriculture engineering's the object, tries to establish a set of scientific and professional evaluation index system of classroom teaching quality through repeated investigation, research and comparison [4]. A series of problems including the complexity of the evaluation factors of professional teaching, the hierarchy of evaluation object, the fuzziness of evaluation criteria, the ambiguity or uncertainty of influence factors of evaluation and the difficulty to quantify the qualitative indicators make it difficult for people to conduct quantitative analysis. However, qualitative analysis alone will produce great fuzziness which is very difficult to be measured with classical mathematical model.

Therefore, the fuzzy comprehensive evaluation method based on fuzzy sets is adopted to carry out comprehensive evaluation on the grades of the evaluation object from multiple indicators. The variation interval of agriculture engineering teaching is divided so that the hierarchy of the object can be taken into account to reflect the fuzziness of evaluation standard and influence factors and the role of people's experience can be brought into full play to make the evaluation results more objective and practical [5]. Fuzzy comprehensive evaluation method expands the amount of information through the combination of qualitative and quantitative factors, improving the evaluation number and making the evaluation results more scientific and reliable.

In reference to the optimization of the Chinese-European joint research projects, this paper carries out the research on the two aspects of the general and professional skills from the three stages of the input, process and output of teaching by interviews, questionnaires and data analysis on the professors, employers, graduates and senior students of agriculture engineering [6]. The specific research method is to carry on the questionnaire survey on the professors, employers, graduates and senior students of agriculture engineering, and the information obtained from the questionnaire are analyzed with fuzzy comprehensive appraisal method. Through the analysis of the data, we put forward the suggestions to improve the curriculum content and teaching process, set up the curriculum standards, thus optimizing the teaching process and improving the quality of education.

\section{INTRODUCTION OF FUZZY COMPREHENSIVE EVALUATION METHOD}

Fuzzy comprehensive evaluation method is a comprehensive evaluation 
method based on fuzzy mathematics. This comprehensive evaluation method transforms the qualitative evaluation into quantitative evaluation according to the membership degree theory of fuzzy mathematics, which means to make a general evaluation of things or objects that are restricted by various factors with fuzzy mathematics [7]. It is characterized with clear and systematic results, which can solve the problem of fuzziness and difficulty in quantifying and is suitable for solving all kinds of problems with uncertainty.

Let the number of factors related to the evaluated matter be $\mathrm{n}$, recorded as:

$U=\left\{u_{1}, u_{2}, \cdots, u_{n}\right\}$

It is called the factor set or index set. And the weight $W=\left\{\mathrm{W}_{1}, \mathrm{~W}, \cdots, \mathrm{W}_{n}\right\}$ is considered to measure the importance of each factor.

Suppose the number of all possible comments is $\mathrm{m}$, recorded as:

$V=\left\{v_{1}, v, \cdots, v_{m}\right\}$

It is called the comment set.

The specific steps are as the following:

(1) Define the factor set $U=\left\{u_{1}, u, \cdots, u_{n}\right\}$;

(2) Determine the evaluation set $V=\left\{v_{1}, v, \ldots, v_{m}\right\}$;

(3) Carry out single factor evaluationto get the membership degree vector, forming the membership degree matrix:
$R=\left[\begin{array}{ccc}r_{11} & \cdots & r_{1 m} \\ \vdots & \ddots & \vdots \\ r_{n 1} & \cdots & r_{m n}\end{array}\right]$

(4) Determine the weight vector of the factor set $W=\left\{\mathrm{w}_{1}, \mathrm{~W}, \cdots, \mathrm{w}_{n}\right\}$

(5) Calculate the comprehensive membership degree vector:

$B=W \bullet R=\left(w_{1}, w, \cdots, w_{n}\right) \bullet\left[\begin{array}{ccc}r_{11} & \cdots & r_{1 m} \\ \vdots & \ddots & \vdots \\ r_{n 1} & \cdots & r_{m n}\end{array}\right\rfloor$

(6) Conduct the evaluationaccording to the maximum principle of membership or calculate the value of comprehensive evaluation.

\section{DATA SURVEY AND PROCESSING}

\subsection{Data survey}

This research project includes the two items of general ability and professional competence with 33 minor terms of the former and 27 of the latter, detailsshown in Table 1. The surveyed people need to score on the "importance" and "acquisition" of every minor item from 1 to 5 points, among which 1 point indicates the minimum importance or acquisition and 5 points represent the maximum [8]. For example, 5 points on the importance means that the ability is very important to the education of agriculture engineering; 5 points on acquisition means that the surveyed object has fully acquired this ability.

Table1: Ability questionnaire

\begin{tabular}{|c|c|c|c|}
\hline \multicolumn{2}{|r|}{ General ability } & \multicolumn{2}{|r|}{ Professional competence } \\
\hline Number value & Ability item & Number value & Ability item \\
\hline No.1 & Analysis and comprehensive ability & No.1 & $\begin{array}{l}\text { With a wide range of professional background knowledge, } \\
\text { understanding of agriculture engineering industry characteristics, } \\
\text { development history and common engineering materials } \\
\text { characteristics }\end{array}$ \\
\hline No.2 & $\begin{array}{l}\text { The ability of applying knowledge in } \\
\text { practice }\end{array}$ & No.2 & Social responsibility consciousness of Agriculture engineering \\
\hline No.3 & Ability to plan and manage time & No.3 & $\begin{array}{l}\text { Ability to independently engage in the original research work of } \\
\text { Agriculture engineering }\end{array}$ \\
\hline No.4 & Knowledge of basic knowledge in the field. & No.4 & $\begin{array}{l}\text { Ability to use modern technology and information tools in engineering } \\
\text { practice. }\end{array}$ \\
\hline No.5 & Ability to apply basic knowledge in practice & No.5 & $\begin{array}{l}\text { Ability of comprehensive coordination and organization and } \\
\text { management of agriculture engineering project }\end{array}$ \\
\hline No.6 & $\begin{array}{l}\text { Oral and written communication skills in } \\
\text { the native language }\end{array}$ & No.6 & $\begin{array}{l}\text { Communication and coordination ability in agriculture engineering } \\
\text { design / construction / management }\end{array}$ \\
\hline No.7 & $\begin{array}{l}\text { Ability to communicate in a foreign } \\
\text { language }\end{array}$ & No.7 & $\begin{array}{l}\text { With the comprehensive quality and leadership in Agriculture } \\
\text { engineering Management }\end{array}$ \\
\hline No.8 & Computing skills & No.8 & Innovative awareness of Agriculture engineering \\
\hline No.9 & Research ability & No.9 & $\begin{array}{l}\text { Ability to analyze, identify and propose solutions to engineering } \\
\text { problems, and be able to submit relevant reports or research papers. }\end{array}$ \\
\hline No.10 & Autonomous Learning Ability & No.10 & $\begin{array}{l}\text { Has the ability to deal with the engineering emergency and } \\
\text { engineering risk management }\end{array}$ \\
\hline No.11 & Information management ability & No.11 & Master basic mechanical principles and analytical methods \\
\hline No.12 & Ability of criticism and self - criticism & No.12 & Basic knowledge of Materials Science \\
\hline No.13 & Ability to adapt to new environment & No.13 & Master and apply the basic principles of structural analysis \\
\hline No.14 & Ability to put forward new ideas & No.14 & $\begin{array}{l}\text { Ability to independently solve basic problems in construction } \\
\text { organization. }\end{array}$ \\
\hline No.15 & Problem solving ability & No.15 & $\begin{array}{l}\text { The ability to apply information technology in agriculture engineering } \\
\text { projects, such as the use of engineering software, etc. }\end{array}$ \\
\hline No.16 & Decision making ability & No.16 & $\begin{array}{l}\text { Ability to implement and analyze the data of interior design of } \\
\text { agriculture engineering. }\end{array}$ \\
\hline No.17 & Team work ability & No.17 & $\begin{array}{l}\text { Ability to solve concrete problems in engineering design and } \\
\text { construction by using engineering geological knowledge }\end{array}$ \\
\hline No.18 & Interpersonal skills & No.18 & $\begin{array}{l}\text { Master the basic principles and methods of basic engineering design } \\
\text { and construction }\end{array}$ \\
\hline No.19 & Leadership & No.19 & Ability to design concepts in the whole life of a project \\
\hline No.20 & $\begin{array}{l}\text { Ability to work across interdisciplinary } \\
\text { teams }\end{array}$ & No.20 & $\begin{array}{l}\text { Ability to obtain and understand the impact of engineering activities } \\
\text { on the natural environment }\end{array}$ \\
\hline
\end{tabular}




\begin{tabular}{|c|c|c|c|}
\hline No.21 & $\begin{array}{l}\text { Ability to communicate with non- } \\
\text { professionals }\end{array}$ & No.21 & $\begin{array}{l}\text { Familiar with the basic working principle of common engineering } \\
\text { equipment and understand its development trend }\end{array}$ \\
\hline No.22 & $\begin{array}{l}\text { Respect and understanding of cultural } \\
\text { diversity }\end{array}$ & No.22 & $\begin{array}{l}\text { The ability to use the building laws and regulations in the construction } \\
\text { management of agriculture engineering projects }\end{array}$ \\
\hline No.23 & $\begin{array}{l}\text { Ability to work in an international } \\
\text { environment }\end{array}$ & No.23 & $\begin{array}{l}\text { Meet the requirements of all agriculture engineering employers on } \\
\text { basic skills }\end{array}$ \\
\hline No.24 & Focus on health and safety & No.24 & Ability to read professional documents using second foreign language \\
\hline No.25 & Active work ability & No.25 & $\begin{array}{l}\text { With the relevant professional knowledge, such as: transportation } \\
\text { planning, urban planning, water supply and drainage, construction } \\
\text { equipment, construction, distribution, etc. }\end{array}$ \\
\hline No.26 & Project design and management skills & No.26 & $\begin{array}{l}\text { With agriculture engineering professional expression, such as } \\
\text { drawing, etc }\end{array}$ \\
\hline No.27 & Innovation and Entrepreneurship & No.27 & .Concept design capability of Agriculture engineering \\
\hline No.28 & Follow social ethics and professional ethics & / & \\
\hline No.29 & $\begin{array}{lll}\begin{array}{l}\text { Social responsibility } \\
\text { consciousness }\end{array} & \text { and } & \text { civic } \\
\end{array}$ & / & \\
\hline No.30 & Quality awareness & / & \\
\hline No.31 & The will of the pursuit of success & / & \\
\hline No.32 & $\begin{array}{l}\text { Environmental awareness and concern for } \\
\text { sustainable development }\end{array}$ & / & \\
\hline No.33 & Self-management ability & 1 & \\
\hline
\end{tabular}

The survey involvesfive colleges and universities namely A, B, C, D and E, and the subjects are professors, employers, students and the graduates. A total of 1041 questionnaires are recovered, and the detailed results are shown in Table 2

Table 2: Survey of the number of distribution table

\begin{tabular}{|c|c|c|c|c|}
\hline & professor & employer & student & graduate \\
\hline A & 63 & 69 & 63 & 63 \\
\hline B & 95 & 0 & 139 & 82 \\
\hline C & 17 & 8 & 74 & 35 \\
\hline D & 37 & 36 & 58 & 10 \\
\hline E & 30 & 94 & 16 & 52 \\
\hline
\end{tabular}

\subsection{Data processing}

An initial screening and analysis of theerror data and unreliable data in the 1041 pieces of data is conducted to delete some data in the following principles:

1. The data with the same score on all theprofessional or general abilities;

2. The data of scores with a specific pattern on the two abilities, $1,2,1,2 \ldots$ $1,2,3,1,2,3 \ldots$
3. The data where more than 50 scores on the importance and acquisition of the general ability are the same;

4. The data where the scores on the acquisition and importance of the general ability are below 10 points;

5. The data where more than 40 scores on the importance and acquisition of the professional ability are the same;

6. The data where the scores on the acquisition and importance of the general ability are below 5 points.

After the data screening and analysis in the above principles, 971 valid data are acquired. The fuzzy comprehensive evaluation method is used to analyze the effective survey data to provide reference for the reform of the teaching of agriculture engineering.

\section{RESULTS ANALYSIS}

\subsection{General ability}

The data analysis of the four kinds of objects on the importance of general abilityis shown in Figure 1. The results reflect that their cognition on the importance of general ability is basically consistent: their scores on the importance of the first 11 items of general ability are similar with small fluctuations on other items. The items with maximum difference in scores are respectively "the ability to work in the international environment", "the ability of active work" and "social responsibility and citizen consciousness".

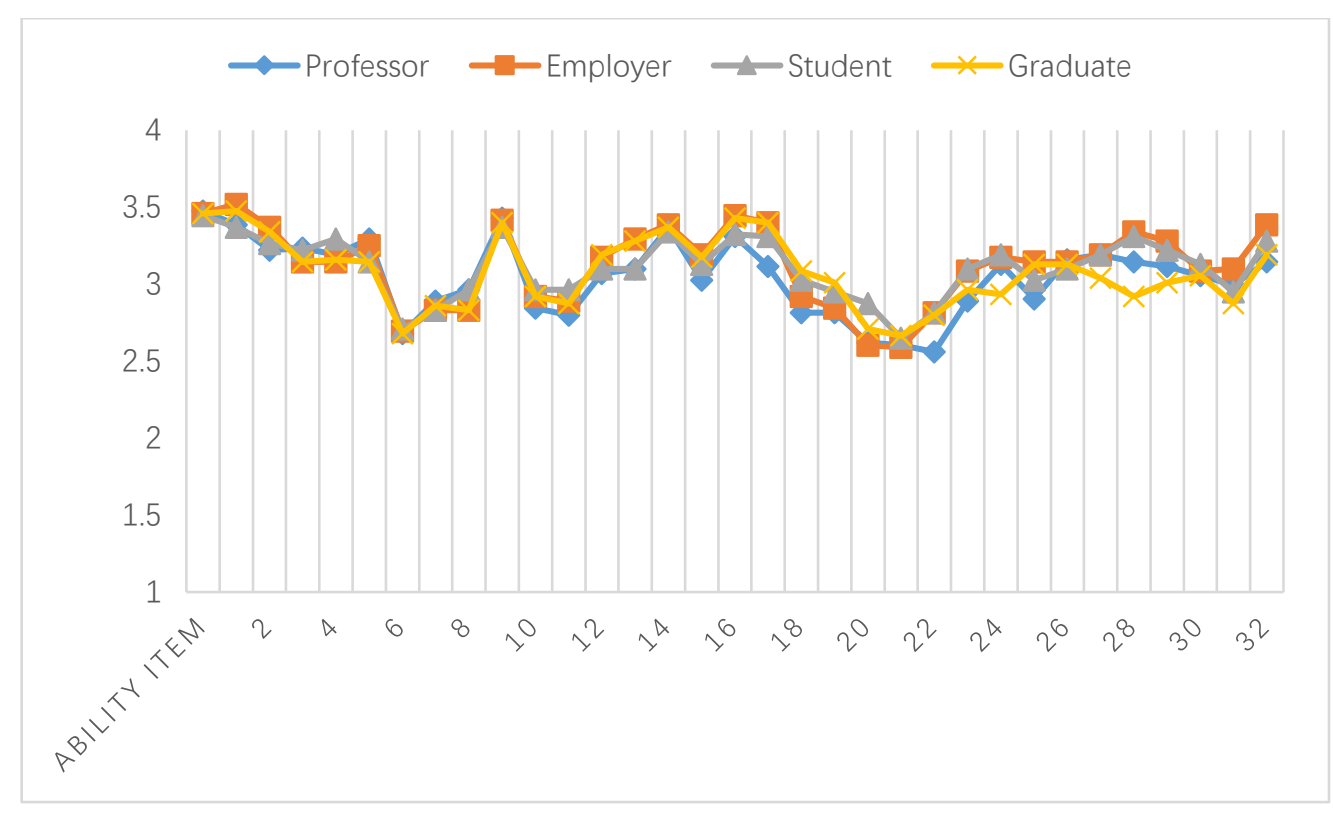

Figure 1: General ability importance 
The data analysis of the four types of objects on acquisition of the general ability is shown in figure 2 . The results reflect that the cognition of the same, but there are great differences with the other two objects with the students and graduates on the acquisition of general ability are almost the

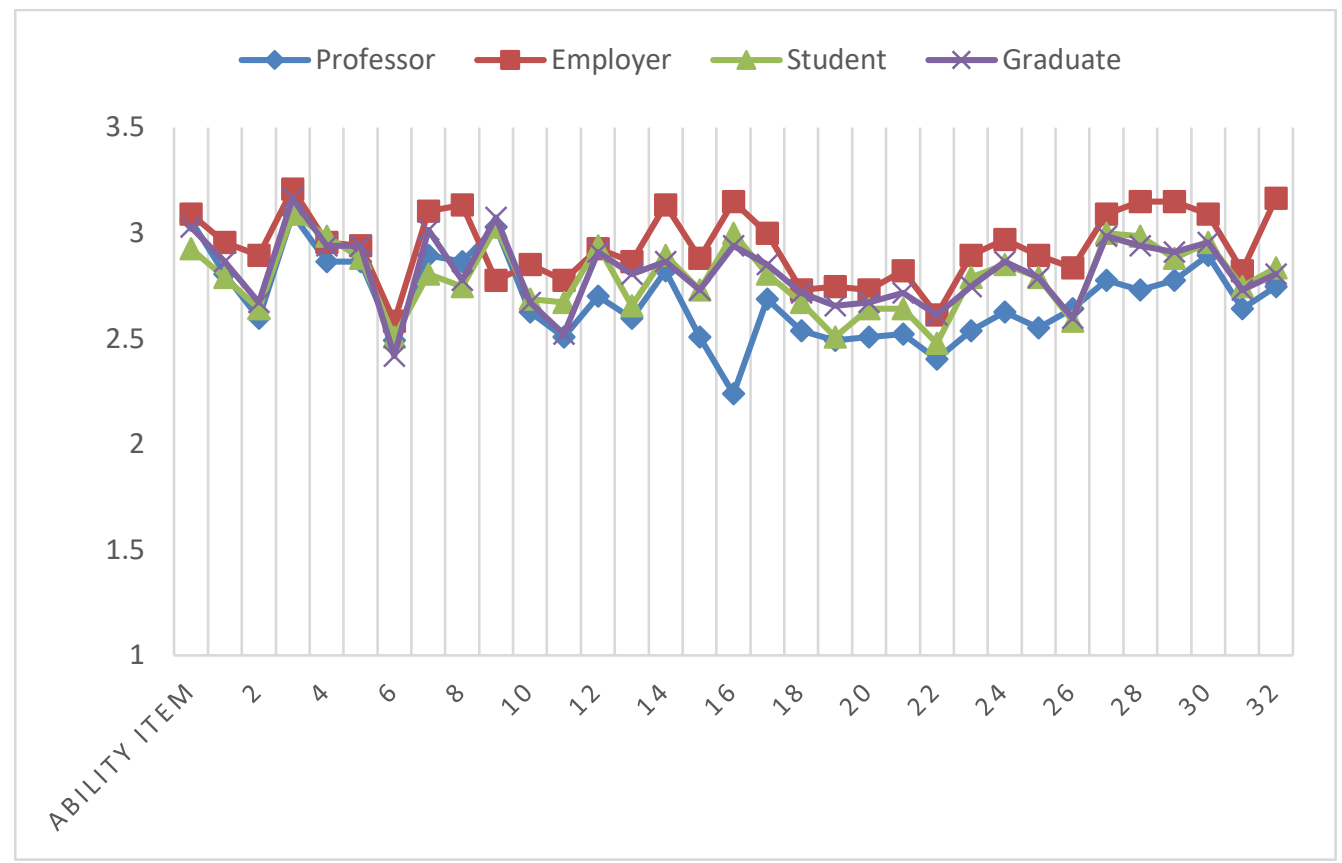

Figure 2: General ability acquisition

Figure 3 is the result of thefuzzy comprehensive evaluationon the importance and acquisition of the general ability.It can be seen that the scores on the importance of general ability are generally higher than that of acquisition, so the teaching of the general abilities should be further strengthened, especially "the ability to apply knowledge into practice", "the ability to plan and manage time", "the ability to put forward new ideas","decision-making ability" and "innovation and entrepreneurship". The scores on the importance and acquisition of the four general abilities including "being familiar with the basic knowledge of the field", "computing skills", "follow social ethics and professional ethics" and "the desire to pursue success" are basically the same, so the teaching of the four skills can maintain the existing teaching methods.It should be noted thatthe acquisition degree of "research ability" is slightly greater than its importance, indicating that the teaching of this ability is excessive and that it can be appropriately reducedin the teaching reform.

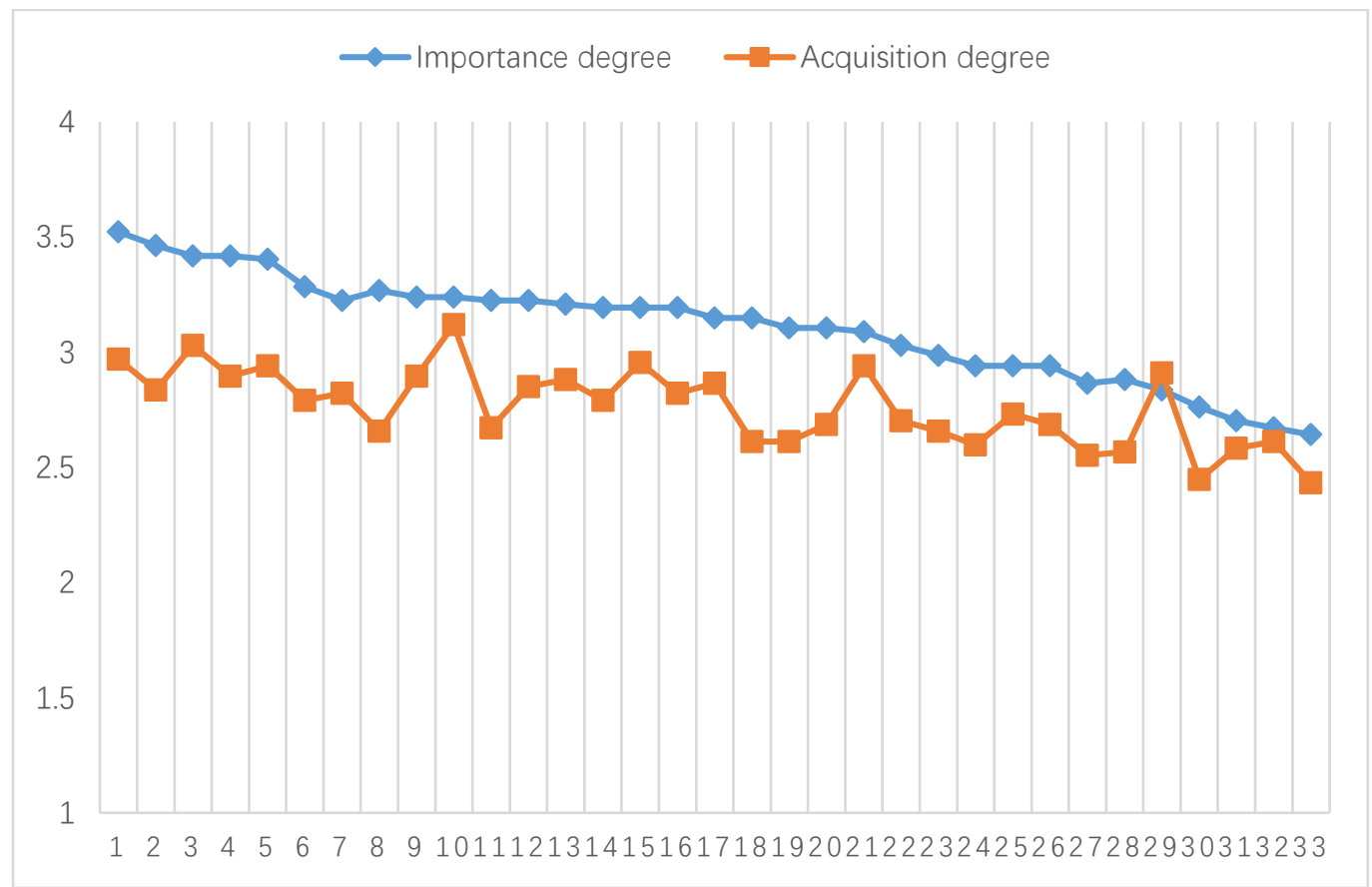

Figure 3: Contrast curve of importance degree and acquisition degree of general ability

\subsection{Professional competence}

The analysis results of thefour kinds of subjects on the importance of professional ability are shown in figure 4 . The results show that their cognitive differences on professional ability mainly exist in two abilities: "with the concept of agriculture engineering design capacity" and "familiar with the basic working principles of common engineering equipment and understanding of its development trend". And the cognition on the importance of the rest professional abilities tends to be consistent. 


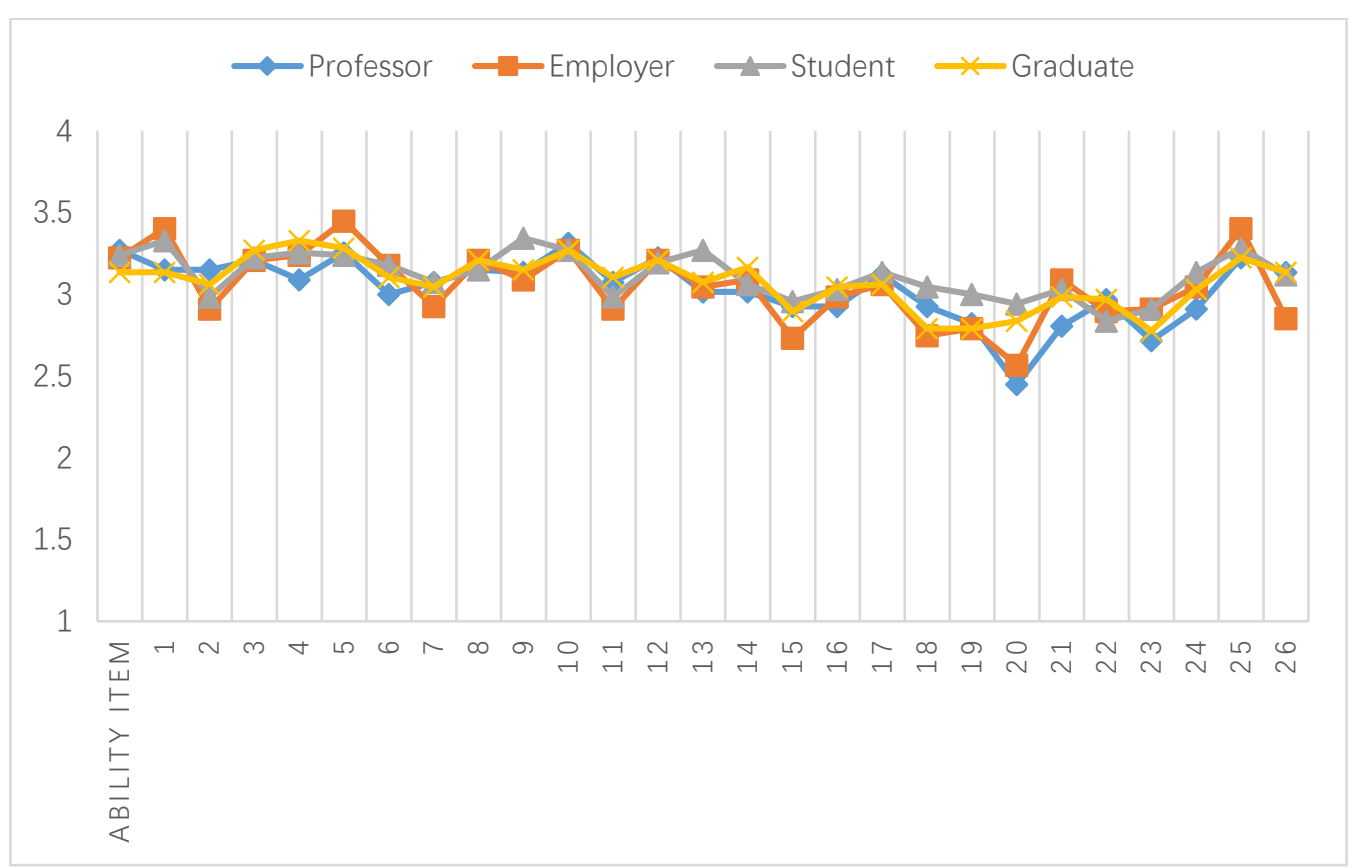

Figure 4: Importance of professional ability

The analysis results of the four kinds of subjects on the acquisition of professional ability are shown in figure 5 . It shows that the rules of the acquisition ofprofessional ability are similar to that of the acquisition of general ability. The scores of the students and graduates are similar, but that of the professors and employers is very different, which is obviously reflected in the ten professional abilities of $2 \sim 3,5 \sim 7$ and 19 23. So attention should be paid to this to enhance the teaching quality of agriculture engineering.

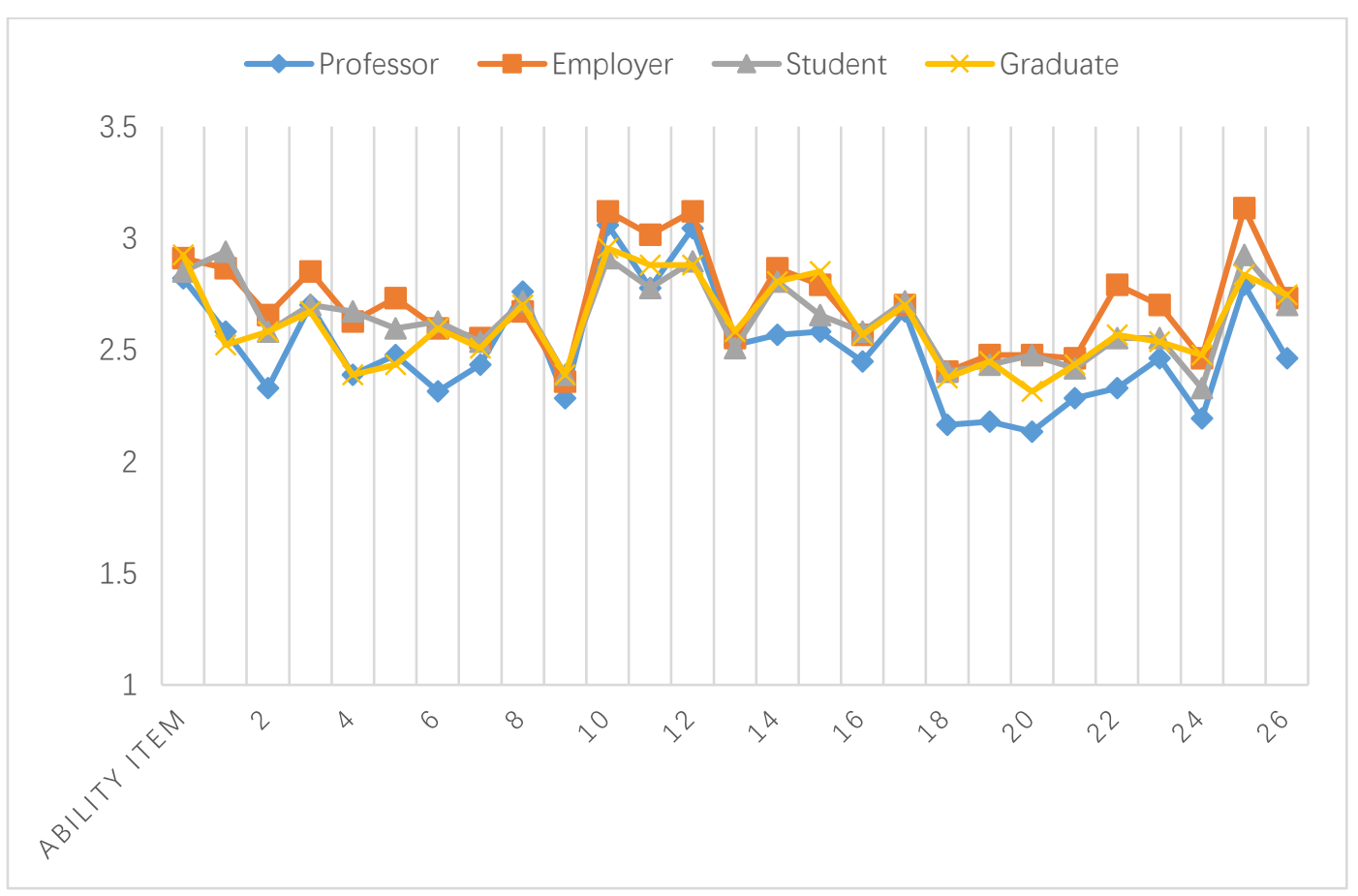

Figure 5: Professional competence acquisition

The analysis results of the fuzzy comprehensive evaluation on the importance and acquisition of the professional abilities of "design of agriculture engineering" and "master the basic knowledge of material" are shown in figure 6. It shows that the scores on the importance of professional ability are generally greater than that of its acquisition; but compared with the general ability, its difference in scores is smaller, which means that the teaching of professional ability is better than that of general ability.But it should be pointed out that the scores on the importance of the four professional abilities including "the comprehensive coordination and organizational management capabilities in agriculture engineering project", "the ability of communication and coordination in the design/construction/management of agriculture engineering", "the ability to cope with engineering emergencies and project risk management" and "with relevant professional basic knowledge, such as: transportation planning, urban planning, water supply and drainage, construction equipment, building power distribution" are significantly higher than that of its acquisition, indicating that the four items are needed to be enhanced in the further teaching reform. However, the scores on the acquisition of "the ability to implement and analyze the data from the interior science" are higher than that of its importance, indicating the needs of weakening its teaching. 


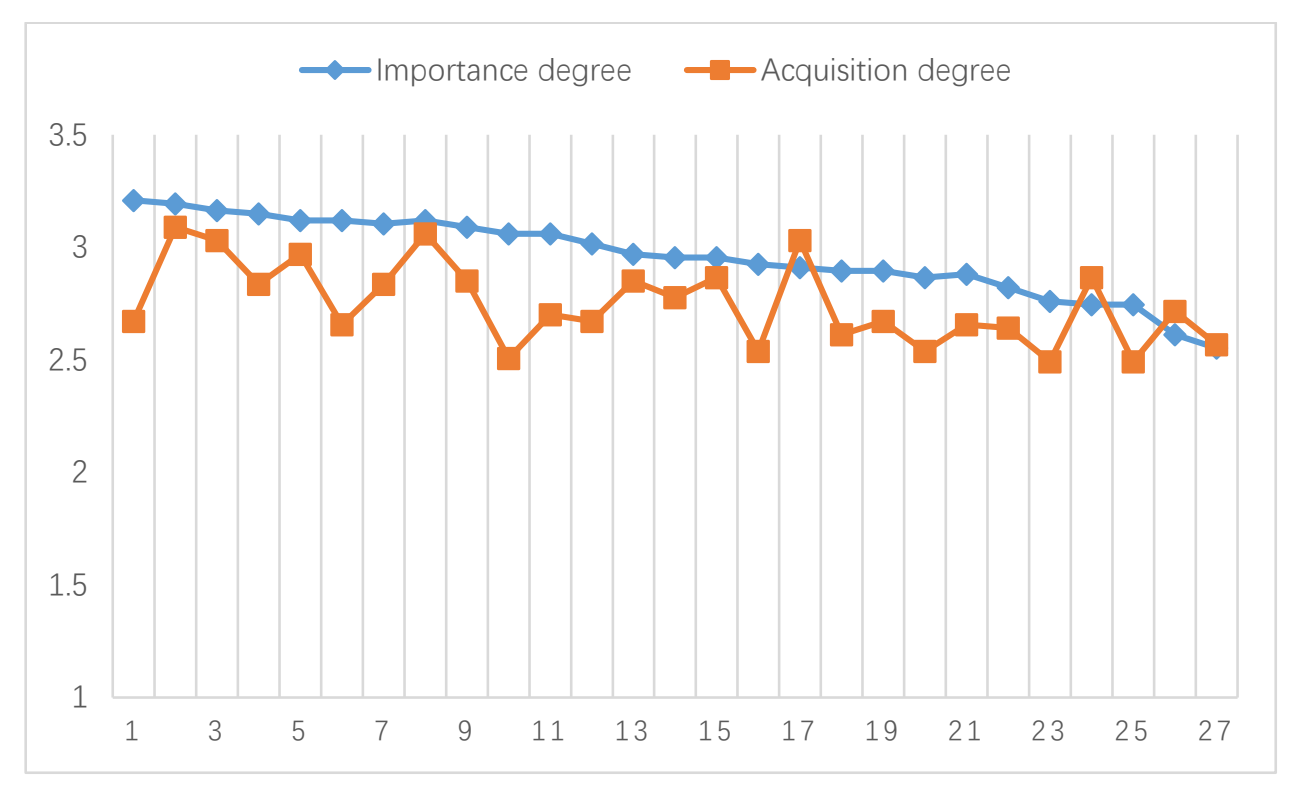

Figure 6: The contrast curve of the importance degree and the acquisition degree of professional ability

\section{CONCLUSIONS}

Teaching evaluation is an important part of the teaching plan of agriculture engineering. According to the characteristics of the agriculture engineering teaching, this paper constructs the teaching evaluation index system of agriculture engineering, and then uses the fuzzy comprehensive evaluation to make the evaluation results more objective and impartial, which greatly improves the scientific of professional teaching and the teaching quality of agriculture engineering.

Based on extensive questionnaire survey, this paper uses the method of fuzzy comprehensive evaluation to analyze and process the data, obtaining the following results: In terms of importance, the awareness of the professor, employers, students and graduates on general and professional competence are relatively high; and as for acquisition, the cognition of the students and graduates is consistent, while there are great differences in that of the professors and employers.

With respect to general ability, the importance scores generally higher than its acquisition. In the teaching reform, the general abilities including "the ability to apply knowledge into practice", "the ability to plan and manage time", "the ability to put forward new ideas", "decision-making ability" and "innovation and entrepreneurship" are urgently needed to be enhanced; the teaching of general abilities including "being familiar with the basic knowledge of the field", "computing skills", "follow social ethics and professional ethics" and "the desire to pursue success" can maintain the current situation; and the teaching of "research abilities" can be appropriately weakened.

At present, the teaching of professional ability is better than that of the general ability. The four professional abilities including "the comprehensive coordination and organizational management capabilities in agriculture engineering project", "the ability of communication and coordination in the design/construction/management of agriculture engineering", "the ability to cope with engineering emergencies and project risk management" and "relevant professional basic knowledge" are urgently needed to be strengthened; the teaching of the two professional abilities of "the ability of design, implementation and the corresponding data analysis of agriculture engineering laboratory test" and "the ability to master basic knowledge of materials science" can be weakened appropriately.

Because this method involves complicated matrix operation, the network can be made full use of to establish a "network-based teaching quality evaluation system" to solve the complex calculation problems. Similarly, the system can also realize online teaching evaluation and score query; therefore, the school teaching departments can keep abreast of the teaching situation of the whole school, and the teaching units can also inquire at any time to understand devaluation the teachers. Most importantly, each teacher can understand all aspects of their assessment and evaluation through the internet, thus enhancing their advantages and avoiding their disadvantages.

\section{REFERENCE}

[1] González, J., Ryan, P.D., Wagenaar, R. 2014. New programme profiles for a new society: an introduction [J]. Tuning journal for higher education, 1 (1), 17-19.

[2] Sun, M., Li, T., Ji, B. 2012. Evaluation Research on Assessment of Clinical Nursing Teaching Quality Based on Fuzzy Comprehensive Evaluation Method []]. Journal of Convergence Information Technology, $7(8)$.

[3] Ellis, R. 2014. Quality Assurance for University Teaching [J].

[4] Hu, X., Zhu, M., Liu, X. 2006. A reform in practical teaching of agriculture engineering specialty [J]. Journal of Architectural Education in Institutions of Higher Learning, 1, 024.

[5] Lin, F., Gu, X., He, M. 2006. Characteristics of modern agriculture engineering and undergraduate program of agriculture engineering specialty [J]. Journal of Architectural Education in Institutions of Higher Learning, 1, 007.

[6] Wan, X., Ding, K. 2010. Practice teaching reformation for agriculture engineering specialty [J]. Journal of Architectural Education in Institutions of Higher Learning, 3, 026.

[7] Xiao-hua, Y. 2005. Research on application personnel training model in agriculture engineering [J]. Journal of Architectural Education in Institutions of Higher Learning, 4, 008.

[8] Rui, P.A.N. 2008. Construction of a New Teaching system for Agriculture engineering Practice [J]. Journal of Architectural Education in Institutions of Higher Learning, 3, 027. 